\title{
The shallow marine ostracod communities of the Azores (Mid-North Atlantic): taphonomy and palaeoecology
}

\author{
R. Piazza Meireles ${ }^{1,2}$ D. Keyser ${ }^{3} \quad$ P.A. Borges ${ }^{4} \quad$ L. Silva $^{1} \quad$ A.M. de Frias Martins ${ }^{1}$ \\ S.P. Ávila ${ }^{1,2,5, *}$
}

${ }^{1}$ CIBIO, Centro de Investigação em Biodiversidade e Recursos Genéticos, InBIO Laboratório Associado, Pólo dos Açores - Departamento de Biologia da Universidade dos Açores

9501-801, Ponta Delgada, Açores, Portugal. Ávila e-mail: avila@uac.pt Silva e-mail: lsilva@uac.pt de Frias Martins e-mail: frias@uac.pt Piazza Meireles: ricomeireles@gmail.com

${ }^{2}$ MPB - Marine PalaeoBiogeography Working Group, University of Azores

Azores, Portugal

${ }^{3}$ Zoological Institute and Museum, University of Hamburg

Martin-Luther-King Platz 3, 20146 Hamburg, Germany. E-mail: keyser@zoologie.unihamburg.de

${ }^{4}$ Department of Geoscience, University of the Azores

Ponta Delgada, Azores, Portugal. E-mail: pb@uac.pt

${ }^{5}$ Faculdade de Ciências da Universidade do Porto

Rua Campo Alegre 1021/1055, 4169-007 Porto

* Corresponding author: tel: +351 296-650101/2; fax: 296-650100; e-mail: avila@uac.pt

\begin{abstract}
This is the first palaeoecological and taphonomical study of the Recent marine ostracods from the Azores. The aims of this work were to address the following questions: i) to establish the typical ostracod assemblages from the shallow waters of the Azores; ii) to determine the bathymetric ranges for each ostracod species; iii) to investigate the time span and depth in which significant transport occurs; iv) to quantify the amount of out of habitat transport between sandy
\end{abstract}


beaches, tide pools and the sublittoral; v) to determine distinctive taphonomic features that can be used to recognize the amount of temporal resolution in ostracod assemblages. Fifteen species were recovered, representing 8 families and 12 genera (Loxoconcha, Neonesidea, Xestoleberis, Aurila, Urocythereis, Heterocythereis, Carinocythereis, Callistocythere, Leptocythere, Semicytherura, Lanceostoma and Cylindroleberis). The living assemblages are dominated by specimens of the Loxoconchidae, Xestoleberidae and Hemicytheridae, whereas the dead assemblages are dominated by specimens of the Loxoconchidae, Hemicytheridae, Bairdiidae, Xestoleberidae and Trachyleberidae. The shift from life-dominated assemblages in the shallower depths to death-dominated assemblages at greater depths is a consequence of significant transport downwards. The abundance of ostracods is higher in the first 10-20 m depth, especially in fine to medium sandy substrates. Considerable differences among islands were supported by the Bayesian model, as a consequence of the physical and hydrodynamic factors that differently affect each of the Azorean islands. Large-scale (sea-surface currents, Holocene relative sea-level, storms) and smallscale processes are responsible for shaping the Azorean Recent marine ostracod communities. No living specimens were found in the samples collected at the beach faces, thus reinforcing former interpretations of one of the authors $(\mathrm{S}$. Ávila) that advocate that at a global scale, sandy beaches in oceanic islands located at temperate latitudes are almost or even completely devoid of life due to historical reasons related with the sea level changes. 
Keywords Ostracods. Recent. Oceanic islands. Taphonomic processes. Palaeoecology. Bayesian model.

\section{INTRODUCTION}

Ostracods are small crustaceans characterized by a bivalved carapace that totally encloses the body and appendages. Their bodies show reduced trunk segmentation and 5-8 pairs of limbs, which protrude from the gaping valves for locomotion. They are typically $0.5-2.0 \mathrm{~mm}$ long in the adult stage (Horne et al., 2002). Ostracods are one of the most diverse groups of living crustaceans, with over 20,000 estimated living species, of which, approximately 8,000 have been described (Morin and Cohen, 1991). Ostracods are particularly sensitive to environmental changes and are, thus, very useful in palaeoenvironmental interpretations (Whatley, 1983; Cronin et al., 2002; Holmes and Chivas, 2002).

Ostracoda fauna differ in the number of families and species around the world, usually, with more species in continental margins than around insular habitats. Owing to their high level of isolation, far-away oceanic islands are a perfect place for the study of evolutionary processes and patterns of dispersal, colonization and speciation (e.g. Schornikov and Keyser, 2004; Wilson, 2007; Ávila et al., 2012). As truly volcanic oceanic islands, the Azores have been the subject of several studies with a biogeographical perspective: molluscs (Ávila and Azevedo, 1997; Ávila, 2000; Ávila et al., 1998, 2000, 2004, 2009a, 2009b; Janssen et al., 2008; Ávila and Sigwart, 2013), sponges (Xavier and van Soest, 2012), algae (Tittley and Neto, 1995). As there are only few published studies on the marine Ostracoda of the Azores (Poulsen, 1972; Angel, 
1973; Meireles et al., 2012), this is an additional contribution to help deciphering the biogeographic puzzle of this region of the Atlantic. Moreover, this study provides important elements for untangling the relationships between different populations and how the environmental stress can determinate the biocenosis (living populations), thanatocoenosis (dead-assemblages, mostly made of disarticulated valves of ostracods, which may contain autochthonous and/or allochthonous elements, depending on the amount of transport) and taphocoenosis (fossil assemblages containing in situ and/or allochthonous fossil elements).

In this work we focused on the Recent shallow marine ostracod biodiversity and abundance, as well as on the taxon geographical and bathymetrical distribution around the archipelago of the Azores, relating the different assemblages with physical (geographical location, degree of exposure to the waves, depth, tidal range), ecological (habitat type, biodiversity) and sedimentological factors that may affect the ostracod communities.

As comparison of invertebrate abundance from recent and old strata depend on the sediment age and history, its granulometry, and the method and type of sample upon which these counts rely on (Kornicker, 1959), a comprehensive taphonomic, ecological, and sedimentological characterization of the study area was done in order to evaluate the influence of the environment and the effect of the depositional processes in shallowwater areas. Specifically, we addressed the following questions: i) is there a typical ostracod assemblage from the shallow marine depths of the Azores?; ii) which is the bathymetric range for each ostracod species?; iii) what is the depth and time span in which significant transport occurs?; iv) when transport occurs, is there a difference in 
the amount of out of habitat transport for sandy beaches, tide pools and the sublittoral?; v) do ostracod assemblages bear distinctive taphonomic features that can be used to recognize the amount of temporal resolution in other deposits?

\section{Study area}

The Azores archipelago is a group of young volcanic oceanic islands that are located in the mid-North Atlantic (Fig. 1) $\left(25-32^{\circ} \mathrm{W}, 37-40^{\circ} \mathrm{N}\right)$, about $1,500 \mathrm{~km}$ from the shores of mainland Portugal. The easternmost Santa Maria Island is the oldest island in the archipelago, having emerged during the Late Miocene (Abdel-Monem et al., 1968, 1975; Féraud et al., 1980, 1981; Ávila et al., 2012) and is very rich in Neogene fossiliferous sediments, including Late Miocene marine ostracods (Meireles et al., 2012).

Today, generally, the coastline of these islands has a NW-SE to WNW-ESE direction, coincident with the major tectonic trends of each of the islands (Borges, 2003). The climate is temperate, with low thermal amplitude, high precipitation, and high air humidity and persistent winds (Calado et al., 2011). Annual average sea-surface temperature is about $19^{\circ} \mathrm{C}$, ranging from $14^{\circ} \mathrm{C}$ in winter to $24^{\circ} \mathrm{C}$ in the summer period (Whissak et al., 2010). The pattern of the sea-surface currents in the North Atlantic is dominated by the Gulf Stream that flows from West to the East, that is, from the American coasts to Europe. One of the branches of the Gulf Stream, the Azores Current, is a meandering jet across the Atlantic at latitude $38^{\circ} \mathrm{N}$, just South of the Azores islands (Johnson and Stevens, 2000; Rogerson et. al., 2004) (Fig. 1). 
The long fetch that characterizes the Azores results in a high-energy wave climate, where both sea and swell are relevant sources of coastal energy, with the northernfacing shore of each island in general being more exposed (Borges et al., 2002). The steep submarine slopes and the absence of large shallow shelves (Borges et al., 2002; Ávila et al., 2008; Quartau et al., 2010, 2012) produce localized patterns of wave shoaling, refraction and diffraction which, especially during storms, occur just before they break, leading to coastal fragmentation into a number of dynamic cells, limited in terms of longshore sediment movement by virtually impermeable lateral boundaries (Borges et al., 2002). The Azores littoral is microtidal to low mesotidal, with tides and tidal currents being minor contributors to coastal morphology and sediment dynamics (Borges et al., 2002). The tides are semidiurnal, with a yearly average and maximum spring tidal range of $0.75-1 \mathrm{~m}$ and $1.3 \mathrm{~m}$, respectively; the storm events are frequent and variable from year to year, with an average recurrent interval of 7 years for extreme events (Borges, 2003).

The transport processes of the coastal sediments are controlled by four main factors: i) steep submarine slopes and absence of large shallow shelves; ii) swell and coastal storms; iii) local sediment supply; and iv) littoral drift currents induced by the Atlantic surface waters. Coastal drift currents are residual, although influenced by the North Atlantic circulation, and have a small effect on the sediment redistribution of the Azorean littoral, being this role attributed mainly to stormy waves that have the capability of disturbing the dynamic cells previously mentioned (Borges, 2003).

Azores coastal forms range from low rocky coasts (some of them with tide pools) to bluffs, plunging cliffs, pocket beaches, dunes, and lagoons. Sandy beaches are not 
common coastal forms, are small, and do not occur in all islands. In plunging cliffs, the intertidal zone is also vertical, with a reduced area available for the settlement of the intertidal organisms. On the subtidal zone, lava rocky shores covered by algae dominate. Unconsolidated sediments are also common, ranging from boulders to sand environments, covering the marine rocky substrate.

\section{MATERIALS AND METHODS}

\section{Collection and examination of specimens}

Three field campaigns were done for this study. The first one was aimed to reveal the characterization and distribution of the beach surface sediments. A total of 600 samples were collected by one of the authors (P. Borges) from 1994 to 1999, which allowed establishing a general sedimentary composition, as well as charts of grain-sized fractions and carbonate contents (Borges, 2003). The second campaign was performed by a team from DOP (University of the Azores) from 1998 to 2008, and collected 20 samples in the inner shelf of the islands of the Central and Western groups, between 20 and $86 \mathrm{~m}$ depth. For the sedimentary samples (first and second campaigns), a subsample of $100 \mathrm{~g}$ of material was retrieved, washed and sieved $(250 \mu \mathrm{m}, 120 \mu \mathrm{m}, 63 \mu \mathrm{m})$ in the laboratory. Subsequently, all ostracod specimens from the same fraction were handpicked under a binocular stereomicroscope, sorted and counted. In accordance with Whatley (1988), species with over 10 valves of adults and juveniles/sample, or adults and last moult stages/sample, were considered as autochthonous on that site. 
The third campaign was done by the first author and collected 27 samples, all containing ostracods with soft parts, therefore assumed to have been living at the time of collection. All biotopes sampled were shallow (less than $15 \mathrm{~m}$ depth), and included intertidal pools and intertidal rocky lava shore platforms. Live ostracods were also collected using a $180 \mu \mathrm{m}$ mesh hand dredge dragged over the bottom surface to a depth of $3-5 \mathrm{~cm}$. The sample was washed through a set of sieves with a mesh width of 1.0 and $0.25 \mathrm{~mm}$. All taxa from the same fraction were sorted, washed in fresh water and fixed in $70 \%$ alcohol in separate tubes.

Of the 647 samples collected, 60 were visually selected, encompassing biogenic carbonate samples from 7 out of the 9 islands of the Azores (only São Jorge and Corvo were not chosen) and of the isolated Formigas islets. These samples were screened for ostracods, which were found in 45 samples (Table 1). A total of 2,799 ostracods were handpicked, containing 586 living ostracods and 2,213 dead specimens (empty or disarticulated valves). Specimens picked from the samples were placed on standard micropalaeontological cavity slides for further examination, classification and counting. Only the autochthonous ostracods (sensu Whatley, 1988) were identified. The taxonomy and classification adopted follows Horne et al. (2002), and both were checked using the WORMS website (http://www.marinespecies.org). A detailed taxonomic description of the ostracod species is out of the scope of this paper and will be dealt with separately. The figured specimens (Fig. 2) are held in the collections of the Department of Biology, University of the Azores, Section of Ostracoda, under prefix "DB/OS". Other abbreviations used: RV=right valve, $\mathrm{LV}=$ left valve.

\section{Statistical analysis}


Several indices were calculated to describe the diversity of the ostracod assemblages: abundance (number of individuals), species richness, Shannon-Wiener diversity and evenness. All ostracod species/specimens were used in the statistical analyses. Data were analyzed using a Bayesian inference with the application WinBUGS (Spiegelhalter et al., 2003). This methodology is an adequate tool for data analysis in ecology (McCarthy, 2007; Kéry, 2010; King et al., 2010) as it allows testing different models in order to determine the possible differences in parameter estimates for different communities (Marcelino et al. 2013). We opted to use Bayesian inference, since all parameters are considered as random variables, thus uncertainty is included at all components of the models (Gelman et al., 1995) which seemed as highly adequate to the type of available data. The best models were selected based on their complexity and fit and also included, as derived quantities, comparisons between community types. They allowed a more comprehensive and easily interpretable approach than the more traditional analysis which usually imply sequential interpretation of multivariate, univariate, and post-hoc tests (Zuur et al., 2007). We used the normal distribution as a prior for Shannon-Wiener diversity and for evenness, and the Poisson distribution for total abundance and species richness (Gelman et al., 1995; McCarthy, 2007; King et al., 2010). The following models were tested: i) island effect model, allowing different parameters for each of the islands; ii) habitat model, allowing different parameters for each habitat type (beach, sublittoral, tide pools); iii) depth model, allowing different parameters for each depth class ( $\leq 10 \mathrm{~m},<30 \mathrm{~m}, \geq 30 \mathrm{~m})$; iv) geographical location model, allowing different parameters for location class (North, South, East, West, Southwest); and v) sediment model, allowing different parameters for sediment diameter size (fine sand, fine to medium sand, medium sand, medium to coarse sand, and coarse sand to gravel). A null model, considering that all the samples belong to the same community, 
was also calculated as a benchmark to compare the validity of the factorial models (we expect the fit of factorial models to be better than that of the null model). Besides estimating the different probability distributions for each community type (group.mean $i)$, we also calculated, as derived quantities, the differences in estimates $\left(d_{i}\right)$ among islands, habitats types, depth classes, location classes and sediment sizes. In all cases we used three Markov chains and updated the model the required number of times to be clearly sufficient to reach convergence, by using normally accepted criteria (King et al., 2010), including analysis of trace plots, the Brooks-Gelman-Rubin diagnostic, and the magnitude of Monte Carlo error, as provided by WinBUGS. To estimate model parameters, we only considered the estimates obtained after convergence. We used Deviance Information Criteria (DIC) as a measure of model complexity and fit (Spiegelhalter et al., 2002). In general, we found that updating the model 100,000 times and using the last 30,000 updates to estimate model parameters and DIC was clearly sufficient to assure chain convergence.

In order to have a global vision of the effect of habitat type (beach, sublittoral, tide pools) on community composition and diversity, we applied a discriminant analysis to a data set including species abundances, total abundance and species richness (all log transformed), and Shannon-Wiener and Equitability diversity indices. The classification module of SPSS v.18 was used.

We used the $\mathrm{R}$ package Indicspecies, available through Cran (http://cran.rproject.org/web/packages/indicspecies/), to determine indicator species among the different habitat types sampled in this study. The package was written by De Cáceres et al. (2010) as a refinement of the IndVal method originally developed by Dufreen and 
Legendre (1997). The algorithm determines both fidelity (restriction to a site or group of sites) and consistency (consistent species occurrence among sites within site groups) and provides a statistic (IndVal) and an associated p-value. Only species significant at the $\mathrm{p}<0.05$ level were selected as indicator species.

\section{RESULTS}

\section{Live Ostracoda assemblages}

Fourteen living species were found: Loxoconcha rhomboidea (Fischer, 1855); Loxoconcha malcomsoni Horne and Robinson, 1985; Neonesidea longisetosa (Brady, 1902); Aurila convexa (Baird, 1850); A. woutersi Horne, 1986; Xestoleberis rubens Whittaker, 1978; Heterocythereis albomaculata (Baird, 1838); Urocythereis britannica Athersuch, 1977; Leptocythere pellucida (Baird,1850); Carinocythereis whitei (Baird, 1850); Callistocythere sp.; Semicytherura sp.; Lanceostoma sp., and Cylindroleberis sp. (Fig. 3; Table 2). Living shallow marine ostracod species were found in tide pools and sublittoral (inner shelf) zones, between 1 and 15-20m depth, in fine to medium sands, usually in association with algae and sponges. Loxoconcha rhomboidea, Xestoleberis rubens, Heterocythereis albomaculata and Loxoconcha malcomsoni were the most abundant species, ranging from $27.5 \%$ to $12.3 \%$ of the total abundance ( $c f$. Table 3 ). In general, Loxoconcha rhomboidea; L. malcomsoni, Neonesidea longisetosa, Xestoleberis rubens and Heterocythereis albomaculata were found living together. The highest concentrations of living ostracods were found on the southern shores of São Miguel Island, at depths ranging from 1 to $15 \mathrm{~m}$. Comparisons of the total number of specimens 
(both live and dead) along a bathymetric sampling (between 0 at $20 \mathrm{~m}$ depth) at all sites in São Miguel Island indicate that there is not a direct relationship between abundance and depth (Fig. 4A). Nevertheless, and excluding the sandy beach habitats, in both living and dead assemblages, the abundance of ostracods is higher in the first $20 \mathrm{~m}$ depth (Fig. 4A, B).

\section{Dead Ostracoda assemblages}

The remains of ostracods (empty carapaces and disarticulated valves) are relatively diverse, comprising 8 families, 12 genera and 15 taxa, and are represented by different ontogenetic stages (instars). The dead assemblages are dominated by specimens belonging to Loxoconchidae (33\%), Hemicytheridae (26\%), Bairdiidae (25\%), Xestoleberididae (7\%) and Trachyleberididae (6\%) (Table 3; Figs. 3; 5).

The sediments with higher ostracod abundance and diversity were collected at depths between 0 and $54 \mathrm{~m}$, where fine to medium sand predominate. The samples with higher ostracod concentration occurred at different depths and places: two samples between 3 and $23 \mathrm{~m}$ in the East and the South coast of Terceira Island, respectively; four samples between 0 and 20m, all in the South coast of São Miguel Island (in this case, two of them were at the same area, around the sewage treatment system of Ponta Delgada); two samples between 10 and $30 \mathrm{~m}$ in the Southwest coast of Faial; and finally, two samples between 1 and 54m, both in the East end of Pico Island (Figs. 3; 5).

\section{Statistical analysis of the factors affecting the ostracod assemblages}


According to the DIC values (Table 4), the more informative Bayesian model (lowest DIC) incorporated the island effect, particularly due to a better adjustment to the possible differences in total abundance between islands. The island model also performed better that the null model for Shannon diversity and species richness. For the factors depth class, habitat type and sediment type, the respective models were better than the null model only for total abundance (Table 4).

The model based on depth only showed differences among depth classes for total abundance (total number of dead ostracods found), with the intermediate depth class (class 2: from 10 to 30m depth) showing the highest abundance (Fig. 6A). Regarding habitat type, the highest abundance was found for communities located at the sublittoral (Fig. 6B) and the lowest number of species was found in the samples collected at beaches (Fig. 6C), where not a single specimen was found alive. The model based on orientation did not show any differences between different orientations (not shown), whereas the model including island effect (Fig. 7A-D) showed many differences among islands, particularly for total abundance (Fig. 7A) and species richness (Fig. 7B). Dead ostracods' total abundance was found to be higher in medium to coarse sands (Fig. 8A), whereas species richness was higher in sands ranging from fine-to-medium, to medium grain size (Fig. 8B).

The results of a discriminant analysis based on individual species abundance, species richness and total abundance (all log transformed), and also on the Shannon-Wiener and evenness diversity indices, showed a good discrimination between ostracod communities collected at different habitats, with a minor overlap between communities 
from beaches and the sublittoral (Fig. 9). The two canonical discriminant functions used in the analysis explain 85.3 and $14.7 \%$ of the detected variance, respectively.

Fine to medium sands are mostly located at depths lesser than $30 \mathrm{~m}$, in places where higher energy environments and turbulence tend to prevail (Fig. 10). At greater depths, in sites where coarse sands to gravel predominate, the faunal autochthonous association is typically composed by species of the genera Loxoconcha, Heterocythereis, Neonesidea, and Urocythereis. As regards to the maximum bathymetric range for species around the Azores insular shelf, Aurila woutersi, Callistocythere sp., Lanceostoma sp., Carinocythereis whitei, Xestoleberis cf. depressa and Loxoconcha malcomsoni are shallow-water species, occurring in waters less than $30 \mathrm{~m}$ depth; Aurila convexa, Xestoleberis rubens, Loxoconcha rhomboidea and Heterocythereis albomaculata may occur between 30 and 55m depth; and Neonesidea longisetosa and Urocythereis britannica may occur as deep as $\sim 90 \mathrm{~m}$ depth. The genera Aurila and Xestoleberis are represented by both littoral species (Aurila woutersi and Xestoleberis cf. depressa) as well as by species occurring at greater depths (Aurila convexa and Xestoleberis rubens) (Fig. 11).

Indic species revealed that Xestoleberis rubens $(0.818, \mathrm{p}=0.015)$ was associated to depth classes $1(<10 \mathrm{~m})$ and $2(10-30 \mathrm{~m})$. Regarding islands, Xestoleberis cf. depressa was associated to Formigas (IndVal $=0.85, \mathrm{p}=0.039$ ), Loxoconcha malcomsoni was associated to Formigas, Terceira and Flores (IndVal $=0.804, \mathrm{p}=0.042$ ), Aurila convexa was associated to São Miguel, Terceira, Pico and Faial, (IndVal=0.881, p=0.033), and Neonesidea longisetosa was associated to Formigas, São Miguel, Terceira, Pico, Faial and Flores (IndVal=0.951, $\mathrm{p}=0,016$ ). Regarding habitat type, Neonesidea longisetosa 
(IndVal $=0.897, \mathrm{p}=0.042)$ and Urocythereis brittanica (IndVal $=0.754, \mathrm{p}=0.032$ ) were found to be associated to the sublittoral.

\section{DISCUSSION}

\section{Taphonomic approach}

The environmental depositional energy can be estimated using sediment grain size and water depth as proxies, and by plotting the samples onto a schematic representation that reflects the taphonomic fidelity of each deposit. These plots can be considered as taphonomically-controlled facies and can be used as predictive tools for estimating how much time-averaging is likely to affect a deposit (see Park et al., 2003 for an overview) (Fig. 10). The Azores shores are considered as a high energy environment, with the exception of a few protected sites (Borges, 2003). In these oceanic islands, dynamic cells make long shore currents to be negligible in comparison with downwelling shore oblique currents, which transport the sediments, moving them from the exposed beach to the underwater beach (cf. Fig. 11) (Borges et al., 2002; Meireles et al., 2013). In these high energy environments, the abundance of ostracods is higher in the sublittoral, at depth ranges of $0-20 \mathrm{~m}$ (Figs. 6A, B), and the diversity is higher in fine to medium- to medium-sandy substrates (Fig. 8B), with less turbulence and thus, with inferred lower energy (cf. Fig. 10).

Kontrovitz et al. (1998) made one equation to discriminate if some taphonomic processes were important in altering an assemblage of ostracods. They showed that such 
assemblages may be sampled and that the width, thickness, and MPS (maximum projection sphericity) of the carapaces could be determined as a function of each species. The amount of pressure required to crush each ostracod carapace could then be estimated by using the equation for that species. If within the assemblage the pressure that would be required to crush the samples varies greatly, then one could conclude that the assemblage is unlikely to have been altered by pressure. Otherwise, the weaker ostracod carapaces probably would have been crushed. If, however, the only ostracods present in the sample require large pressures to be crushed or all require about the same pressure, then one might suspect that the assemblage may have lost carapaces/species due to forces exerted by the overlying sediments. Under the latter conditions, the investigator could misinterpret palaeoenvironmental conditions, if wrongly assuming the presence of a nearly complete and useful assemblage for such a purpose (Kontrovitz et al., 1998). Moreover, models that rely exclusively on death assemblages will be always less informative than those based upon live assemblages (Park et al., 2003). Our samples include a mixture of fragile and resistant carapaces, the latter being predominant (cf. Fig. 2). As expected, fragile carapaces of shallow-water species (e.g., Lanceostoma sp.) are better represented in the shallow (and more recent) samples than in the deeper ones (which are also older and were subjected to transport). Thus, transport of sediment becomes an important item that must be taken into account when ostracods are used as proxy indicators for biodiversity and conservation practices in steep gradient coasts such as those around the Azores islands, and should be included in any model developed (cf. Fig. 10).

Other important components that are present in the taphonomic studies are the synecology indices (i.e. describing associations in relation to environmental parameters), which are based on the quantitative analysis of the assemblages and that 
may shed light on the stability of the environment. Low diversity assemblages with few or single dominating species point to stressed, unstable conditions (Frenzel and Boomer, 2005). For instance, high sedimentation rates, recorded for areas of the Baltic Sea, showed low diversity and abundance (Rosenfeld, 1977). The number of autochthonous dead specimens decreases with depth, suggesting a shift from life-dominated assemblages in the shallower depths, to death assemblages (with autochthonous and allochthonous specimens) at greater depths (Fig. 4B). This trend is expected when significant transport occurs and is in agreement with Park et al. (2003) and Machado et al. (2005).

The abundance of the Azorean ostracod species is related to depth (Figs. 4B; 6A), grain size (Fig. 8A), and geographical coast location (Fig. 7A). The higher abundance of ostracods in the southern and eastern shores is probably a result of a relatively higher stability of the bottom sediments during longer periods in these sites, as the mean wave height in the northern coasts exceeds up to $20 \%$ the value of the southern coasts (cf. Borges, 2003). We cannot, however, exclude that these deposits and their faunas have undergone transport, particularly in areas with higher-energy conditions, by downwelling shore oblique currents.

Comparison of live and dead assemblages from similar depths and substrates around the archipelago indicates that there are some distribution oddities. For example, all species presently known in the Azores occurred at Terceira Island, with the exception of Lanceostoma sp. However, this species also occurs at Graciosa Island, just 60km distance. Santa Maria Island and Formigas Islets (about $38 \mathrm{~km}$ apart) have similar 
species composition, except for Neonesidea longisetosa that is not present at Santa Maria (cf. Fig. 5).

The standard of length classes' distribution present in one taphocoenosis can be used to describe how the death of the animals occurred (Shipman, 1981). Using this method plus the ontogenetic structure of the populations (after Whatley, 1988; cf. Electronic Appendix, available at www.geologica-acta.com), we identified two different types of death: i) non-selective death (i.e., catastrophic, affecting in a similar manner both juveniles and adults); and ii) selective death (natural, thus with different mortality rates). Most of the samples present a selective death (natural) with the exception of samples 6 , 7, 9, 25 and 32 (cf. Table 1) that present a non-selective death (catastrophic). In general, the samples collected in protected sites or on the South shores of the islands present a selective death (natural), probably with fast burial (e.g., assemblages $n^{\circ} 4,12,31 ; c f$. Figs. 3 ; 5). These areas present a reduced hydrodynamism and thus, probable higher sedimentation rates. Based on these findings and the characteristics of the present-day taxa we were able to develop a model of how assemblages occur on these settings, relating these items with the bathymetric range of the ostracod species (Fig. 11). Considering the type of substrate, depth and marine environment (tide pools, beach and sublittoral), we were able to display the distribution of the autochthonous ostracods on the insular Azorean shelf (see complete list of the typical association of species in Supplementary Electronic Appendix).

\section{Ecological setting}


In terms of abundance (number of specimens/100g dry sediment), we found considerable variation between samples, a situation that is in agreement with previous studies (cf. Figs. 6; 7; 8). Allison and Holden (1971) described differences in abundance, depending on the depth, with relatively lower values closer to the surface. Hull (1997) reported that abundances differ over the years, and also along the year. In Brazil, species abundance was higher than the values reported for the Azores (50 to 150 individuals/100g dry sediment), with some samples with abundances over 1,000 specimens $/ 20 \mathrm{~g}$ dry sediment, and also showing the already noted variation between samples (Machado et al., 2005). Cabral et al. (2006) reported abundances between 10 to 100 specimens $/ 10 \mathrm{~cm}^{3}$ sediment, depending on the area, for the Melides lagoon $(80 \mathrm{~km}$ south of Lisbon, mainland Portugal). Athersuch (1979) found similar abundance values for the littoral of Cyprus, with some species with more than 100 specimens/sample. For the Basque shelf, abundances were also similar, ranging from 11 to 156 specimens/sample (Pascual et al., 2008).

If we consider ostracods as a grain of sand, the zonation displayed on Figure 9 suites well with the coastal fragmentation into dynamic cells, limited in terms of longshore sediment movement by virtually impermeable lateral boundaries where the dynamics of the beaches are essentially transverse to the shore (cf. Borges et al., 2002), and with a morphodynamic continuum between two extreme situations, the profile of high energy (storm or winter profile) and the profile of low energy (swell or summer profile), with the sandy sediments moving from the exposed beach to the underwater beach and viceversa, respectively (see Short (1999) for an overview). 
Ostracod species richness assessments depend on the depth of collection, as the estimates are differently impacted by time-averaging. This is so, because transport of dead valve material occurs at higher percentages in the shallow depths and on the sublittoral. As a result of this, the biogenic material will accumulate at higher depths, suggesting that the well-preserved ostracod death assemblages in these areas will be a mirror of shallow and sublittoral life assemblages. However, caution must be taken, as below storm-wave base, both autochthonous and allochthonous species will be concentrated in the same area (Meireles et al., 2013). The beach areas do not emulate the life assemblages, as all species are considered to be allochthonous, thus did not live there (moreover, following Whatley (1988), all samples also had fewer than 10 specimens/sample).

Several environmental factors affect the distribution and abundance of ostracods, in particular, the textural characteristics of the bottom substrate. Benson and Maddocks (1964), Puri (1966), Montenegro et al. (1998) and Coimbra et al. (1999) reported that grain size is one of the significant factors controlling the population structure, density and distribution of ostracod species, fine-grained sands with a high percentage of silt and clay being favoured (Machado et al., 2005). High algal concentrations and seasonal changes can also influence the presence of ostracods (Hull, 1997). Furthermore, other factors like depth also affect ostracods richness. For instance, Ascoli (1964) found that the most favourable environmental conditions for a high number of ostracod species was a depth between 50 and $250 \mathrm{~m}$, on a muddy and clayey bottom; towards either upper littoral or bathyal environments, the number of species decreased. Our observations showed more species at the sublittoral than at the beach faces (Fig. 9). However, tide pools seem to be an exception, deserving further studies. Besides sediment size and 
water depth, the morphology of the coast might also be important; for example, living ostracods in Kuwait Bay were abundant except in the tidal flat areas and the central channel (Al-Abdul-Razzaq et al. 1983).

With all these factors affecting ostracods occurrence, it is not surprising that considerable differences among islands have been found (Fig. 7), since all factors might interact differently at each Azorean island, as demonstrated by the more informative Bayesian model, the Island effect ( $c$. DIC values in Table 4). Also, habitat types, by differently combining several of the above mentioned factors (e.g. depth, size of the sediment, coastal morphology) were clearly discriminated in this study. Thus, in regards to the shaping of the Recent Azorean ostracod communities, we might be in the presence of large-scale (sea-surface currents, Holocene relative sea-level, storms) and small-scale processes (geographical location, coastal fragmentation into dynamic cells with impermeable lateral boundaries, morphology of the coast, seafloor stability of the sediments).

\section{CONCLUSIONS}

This is the first palaeoecological study of the Recent ostracods from the Azores. So far, only two species had been reported: Loxoconcha rhomboidea and Heterocythereis albomaculata (Costa, 2010). This work increases the number of benthic shallow-water marine ostracods from this archipelago to 15 species, representing 8 families and 12 genera (Loxoconcha, Neonesidea, Xestoleberis, Aurila, Urocythereis, Heterocythereis, 
Carinocythereis, Callistocythere, Leptocythere, Semicytherura, Lanceostoma and Cylindroleberis; $c f$. Table 3; Fig. 2).

The living assemblages are dominated by specimens of the Loxoconchidae, Xestoleberidae and Hemicytheridae, whereas the dead assemblages are dominated by specimens of the Loxoconchidae, Hemicytheridae, Bairdiidae, Xestoleberidae and Trachyleberidae. The most abundant species, Loxoconcha rhomboidea, occurred in both living (0-20m depth) and dead assemblages, and together with Neonesidea longisetosa, Xestoleberis rubens and Heterocythereis albomaculata outlines an assemblage of species that are usually found together in the living assemblages. The shift from lifedominated assemblages in the shallower depths to death assemblages at greater depths is a consequence of significant transport downwards.

Interestingly, no living specimens were found in the samples collected at the beach faces, thus reinforcing the interpretations of Ávila et al. (2008) and Ávila (2013) who advocate that at a global scale, sandy beaches in oceanic islands located at temperate latitudes are almost or even completely devoid of life due to historical reasons related with the sea level changes: every time sea level drops below the insular shelf edge as a result of a glacial episode, sand grains slip along the steep insular slope and get lost to the abyssal depths. As expected, all shallow-water species associated to sandy environments are also lost (and thus these species are extirpated from the island). Moreover, this process has happened repeatedly during the several Pleistocene glacial episodes that impacted such oceanic islands, promoting successive events of local disappearances and thus explaining the reduced number (or even the non-existence) of 
endemic invertebrates associated to the shallow sandy environments of oceanic islands (Ávila, 2013; Ávila et al., 2008).

The new information herein provided by the marine ostracods of the Azores and the sustained development of this new research line, for which the present work is a first contribution, will most likely bring novel palaeoecological and taphonomic ideas to the global understanding of the Azorean shallow marine biota, both Recent and fossil.

\section{ACKNOWLEDGMENTS}

We thank the Direcção Regional da Ciência, Tecnologia e Comunicações (Regional Government of the Azores), Direcção Regional do Ambiente e do Mar (Regional Government of the Azores) and FCT (Fundação para a Ciência e a Tecnologia) of the Portuguese government for financial support. We would like also to thank Filipe Porteiro and Valentina Matos (IMAR-Azores); Joana Xavier and Andreia Cunha (CiBio-Azores) for loaning samples and Jorge Medeiros (CIRN/University of the Azores) for the SEM photographic support. Ricardo Piazza Meireles benefited from a grant SFRH/BD/60518/2009 of FCT, Portugal. Sérgio Ávila acknowledges his Ciência 2009 research contract funded by FCT.

\section{REFERENCES}

Abdel-Monem, A., Fernandez, L.A., Boone, G.M., 1968, Pliocene-Pleistocene minimum K-Ar ages of the older eruptive centers, Eastern Azores. Transactions, American Geophysical Union, 49(1), 363. 
Abdel-Monem, A., Fernandez, L.A., Boone, G.M., 1975. K/Ar ages from the eastern Azores group (Santa Maria, São Miguel and the Formigas Islands). Lithos, 4, 247-254.

Al-Abdul-Razzaq, S., Shublaq, W., Al-Sheikh, Z., Kittaneh, W., 1983. Ecology and distribution of ostracods in Kuwait Bay. Journal of Micropalaeontology, 2, 39-45.

Allison, E.C., Holden, C.H., 1971. Recent Ostracodes from Clipperton Island Eastern Tropical Pacific. San Diego Society of Natural History, 16(7), 165-214.

Angel, M.V., 1973. The description of the female of the ostracod Bathyconchoecia sagittarius Deevey, 1968 (Myodocopida, Halocyprididae). Crustaceana, 25, 211-219.

Ascoli, P., 1964. Preliminary ecological study on Ostracoda from bottom cores of the Adriatic Sea. Pubblicazioni della Stazione Zoologica di Napoli, 33 (supplement), 213-246.

Athersuch, J., 1979. The ecology and distribution of the littoral ostracods of Cyprus. Journal of Natural History, 13, 135-160.

Ávila, S.P., 2000. Shallow-water marine molluscs of the Azores: biogeographical relationships. Arquipélago. Life and Marine Sciences. Supplement 2 (Part A), 99-131.

Ávila, S.P., 2013. Unravelling the patterns and processes of evolution of marine life in oceanic islands: a global framework. In: Fernández-Palacios, J.M., Nascimento, L., Hernández, J.C., Clemente, S., González, A., Díaz-González, J.P. (eds.). Climate Change perspectives from the Atlantic: past, present and future. Tenerife, Universidad de La Laguna, 85-115.

Ávila, S.P., Azevedo, J.M.N., 1997. Shallow-water molluscs from the Formigas islets, Azores, collected during the "Santa Maria e Formigas 1990" scientific expedition. Açoreana, 8(3), 323-330.

Ávila, S.P., Sigwart, J., 2013. New records for the shallow-water chiton fauna (Mollusca, Polyplacophora) of the Azores (NE Atlantic). ZooKeys, 312, 23-38. DOI: 10.3897/zookeys.312.4768.

Ávila, S.P., Azevedo, J.M.N., Gonçalves, J.M., Fontes, J., Cardigos, F., 1998. Checklist of the shallow-water marine molluscs of the Azores: 1 - Pico, Faial, Flores and Corvo islands. Açoreana, 8(4), 487-523. 
Ávila, S.P., Azevedo, J.M.N., Gonçalves, J.M., Fontes, J., Cardigos, F., 2000. Checklist of the shallow-water marine molluscs of the Azores: 2 - São Miguel island. Açoreana, 9(2), 139173.

Ávila, S.P., Cardigos, F., Santos, R.S., 2004. D. João de Castro bank, a shallow-water hydrothermal-vent in the Azores: checklist of the marine mollusks. Arquipélago. Life and Marine Sciences, 21A, 75-80.

Ávila, S.P., Madeira, P., Marques da Silva, C., Cachão, M., Landau, B., Quartau, R., Frias Martins, A.M.de, 2008. Local disappearance of bivalves in the Azores during the last glaciation. Journal of Quaternary Science, 23, 777-785.

Ávila, S.P., Madeira, P. Zazo, C., Kroh, A., Kirby, M., Silva, C.M., Cachão, M., Martins, A.M.F., 2009a. Palaeocology of the Pleistocene (MIS 5.5) outcrops of Santa Maria Island (Azores) in a complex oceanic tectonic setting. Palaeogeography, Palaeoclimatology, Palaeoecology, 274, 18-31.

Ávila, S.P., Silva, C.M., Schiebel, R., Cecca, F., Backeljau, T., Martins, A.M.F., 2009b. How did they get here? Palaeobiogeography of the Pleistocene marine molluscs of the Azores. Bulletin of the Geological Society of France, 180, 295-307.

Ávila, S.P., Ramalho, R., Vullo, R., 2012. Systematics, palaeoecology and palaeobiogeography of the Neogene fossil sharks from the Azores (Northeast Atlantic). Annales de Paléontologie, 98, 167-189

Benson, R.H., Maddocks, R.L., 1964. Recent Ostracodes of Knysna Estuary, Cape Province, Union of South Africa. University of Kansas Paleontological Contributions, 5, 1-39.

Borges, P., 2003. Ambientes litorais nos grupos Central e Oriental do Arquipélago dos Açores. Ph.D. Thesis. Ponta Delgada, Universidade dos Açores, 413pp.

Borges, P., Andrade, C., Freitas, C., 2002. Dune, bluff and beach erosion due to exhaustive sand mining - the case of Santa Bárbara, S. Miguel (Azores, Portugal). Journal of Coastal Research, 36 (Special Issue), 89-95.

Cabral, M.C., Freitas, M.C., Andrade, C., Cruces, A., 2006. Coastal evolution and Holocene ostracods in Melides lagoon (SW Portugal). Marine Micropaleontology, 60, 181-204. 
Calado, H., Borges, P., Phillips, M., Ng, K., Alves, F., 2011. The Azores archipelago, Portugal: improved understanding of small island coastal hazards and mitigation measures. Natural Hazards, 58, 427-444.

Coimbra, J.C., Pinto, I.D., Wqrdig, N.L., Carmo, D.A., 1999. Zoogeography of Holocene Podocopina Ostracoda from the Brazilian equatorial continental shelf. Marine Micropaleontology, 37, 365-379.

Costa, A.C., 2010. List of coastal marine invertebrates. In: Borges, P.A.V., Costa, A., Cunha, R., Gabriel, R., Gonçalves, V., Martins, A.F., Melo, I., Parente, M., Raposeiro, P., Rodrigues, P., Santos, R.S., Silva, L., Vieira, P., Vieira, V. (eds.). A list of the terrestrial and marine biota from the Azores. Cascais, Princípia, 287-324.

Cronin, T.M., Boomer, I., Dwyer, G., Rodríguez-Lázaro, J., 2002. Ostracoda and Paleoceanography. In: Holmes, J., Chivas, A.R. (eds.). The Ostracoda. Applications in Quaternary Research. Washington, American Geophysical Union, 99-119.

De Cáceres, M., Legendre, P., Moretti, M., 2010. Improving indicator species analysis by combining groups of sites. Oikos, 119, 1674-1684.

Dufrene, M., Legendre, P., 1997. Species assemblages and indicator species: the need for a flexible asymmetrical approach. Ecological Monographs, 67, 345-366.

Feraud, G., Kaneoka, I., Allègre, C.J., 1980. K-Ar ages and stress pattern in the Azores: geodynamic implications. Earth and Planetary Science Letters, 46, 275-286.

Feraud, G., Schmincke, H.U., Lietz, J., Gastaud, J., Pritchard, G., Bleil, U., 1981. New K-Ar Ages, Chemical Analyses and Magnetic Data of Rocks from the Islands of Santa Maria (Azores), Porto Santo and Madeira (Madeira Archipelago) and Gran Canaria. Bulletin of Volcanology, 44(3), 359-375.

Frenzel, P., Boomer, I., 2005. The use of ostracods from marginal marine, brackish waters as bioindicators of modern and Quaternary environmental change. Palaeogeography, Palaeoclimatology, Palaeoecology, 225, 68-92.

Gelman, A., Carlin, J.B., Stern, H.S., Rubin, D.B., 1995. Bayesian Data Analysis. London, Chapman \& Hall, 689pp. 
Holmes, J.A., Chivas, A.R., 2002. The Ostracoda. Applications in Quaternary Research. Washington, American Geophysical Union, 185-203.

Horne, D.J., Cohen, A., Martens, K., 2002. Taxonomy, morphology and biology of Quaternary and living ostracoda. In: Holmes, J.A., Chivas, A.R. (eds.). The Ostracoda. Application in Quaternary Research. Washington, Geophysical Monograph, 131, 5-36.

Hull, S.L., 1997. Seasonal changes in ostracod abundance and diversity on four species of algae with differing structural complexity. Marine Ecology Progress Series, 161, 71-82.

Intergovernmental Oceanographic Commission (IOC), International Hydrographic Organization (IHO), British Oceanographic Data Center (BODC), 2003. Centenary Edition of the GEBCO Digital Atlas, published on CD-ROM on behalf of the Intergovernmental Oceanographic Commission and the International Hydrographic Organization as part of the General Bathymetric Chart of the Oceans. British Oceanographic Data Centre, Liverpool, U.K.

Janssen, A.W., Kroh, A., Ávila, S.P., 2008. Early Pliocene heteropods and pteropods (Mollusca, Gastropoda) from Santa Maria (Azores, Portugal): systematics and biostratigraphic implications. Acta Geologica Polonica, 58, 355-369.

Johnson, J., Stevens, I., 2000. A fine resolution model of the eastern North Atlantic between the Azores, the Canary Islands and the Gibraltar Strait. Deep-Sea Reserch part I, 47, 875-899.

Kéry, M., 2010. Introduction to WinBUGS for Ecologists. A Bayesian approach to regression, ANOVA, mixed models and related analyses. Burlington, MA., Academic Press, Elsevier, $302 \mathrm{pp}$.

King, R., Morgan, B.J.T., Gimenez, O., Brooks, S.P., 2010. Bayesian analysis for Population Ecology. Boca Raton, Chapman \& Hall/CRC, 456pp.

Kontrovitz, M., Pani, E.A., Bray, H., 1998. Experimental crushing of some podocopid ostracode valves: an aspect of taphonomy. Palaios, 13(5), 500-507.

Kornicker, L.S., 1959. Analysis of factors affecting quantitative estimates of organism abundance. Journal of Sedimentary Petrology, 29(4), 596-601. 
Machado, C.P., Coimbra, J.C., Carrenõ, A.L., 2005. The ecological and zoogeographical significance of the sub-Recent Ostracoda of Cabo Frio, Rio de Janeiro State, Brazil. Marine Micropaleontology, 55, 235-253.

Marcelino, J.A.P., Silva, L., Garcia, P.V., Weber, E., Soares, A.O., 2013. Using species spectra to evaluate plant community conservation value along a gradient of anthropogenic disturbance. Environmental Monitoring and Assessment, 185, 6221-6233.

McCarthy, M.A., 2007. Bayesian Methods for Ecology. Cambridge, UK., Cambridge University Press, 306pp.

Meireles, R.P., Faranda, C., Gliozzi, E., Pimentel, A., Zanon, V., Ávila, S., 2012. Late Miocene marine Ostracodes from Santa Maria Island, Azores (NE Atlantic): Systematics, Palaeoecology and Palaeobiogeography. Revue de Micropaléontologie, 55, 133-148.

Meireles, R.P., Quartau, R., Ramalho, R., Rebelo, A.C., Madeira, J., Zanon, V., Ávila, S.P., 2013. Depositional processes on oceanic island shelves - evidence from storm-generated Neogene deposits from the Mid North Atlantic. Sedimentology, 60, 1769-1785. DOI: $10.1111 /$ sed. 12055

Montenegro, M.E., Pugliese, N., Bonaduce, G., 1998. Shelf ostracods distribution in the Italian seas. In: Crasquin-Soleau, S., Braccini, E., Lethiers, F. (eds.). What About Ostracoda! Paris-Bierville, Elf Ep-Editions, 317-327.

Morin, J.G., Cohen, A.C., 1991. Bioluminescent displays, courtship, and reproduction in ostracodes. In: Bauer, R.T., Martin, J.W., (eds.). New York, Columbia University Press, 116.

Park, L.E., Cohen, A.S., Martens, K., 2003. The impact of taphonomic processes on interpreting paleoecologic changes in large lake ecosystems: ostracodes in Lakes Tanganyika and Malawi. Journal of Paleolimnology, 30, 127-138.

Pascual, A., Rodriguez-Lazaro, J., Martín-Rubio, M., Jouanneau, J-M., Weber, O., 2008. A survey of the benthic microfauna (foraminifera, Ostracoda) on the Basque shelf, southern Bay of Biscay. Journal of Marine Systems, 72, 35-63. 
Poulsen, E.M., 1972. On the Bathyconchoecia (Ostracoda, Myodocopa) from the Azores collected by the bathyscaphe "Archimede" in 1969. Tethys, 4, 445-456.

Puri, H.S., 1966. Ecological distribution of Recent Ostracoda. Proceeding in the Symposium of Crustacea, 457-495.

Quartau, R., Trenhaile, A.S., Mitchell, N.C., Tempera, F., 2010. Development of volcanic insular shelves: Insights from observations and modelling of Faial Island in the Azores Archipelago. Marine Geology, 275, 66-83.

Quartau, R., Tempera, F., Mitchell, N.C., Pinheiro, L.M., Duarte, H., Brito, P.O., Bates, C.R., Monteiro, J.H., 2012. Morphology of the Faial Island shelf (Azores): the interplay between volcanic, erosional, depositional, tectonic and mass-wasting processes. Geochemistry, Geophysics, Geosystems, 13(4), 1-30. DOI:10.1029/2011GC003987

Rogerson, M., Rohling, E.J., Weaver, P.P.E., Murray, J.W., 2004. The Azores Front since the Last Glacial Maximum. Earth and Planetary Science Letters, 222, 779-789.

Rosenfeld, A., 1977. Die rezenten Ostracoden-Arten der Ostsee. Meyniana, 29, 11-49.

Schornikov, E.I., Keyser, D., 2004. The morphology and classification of Lanceostomatinae (Ostracoda) from the nearshore zone of Madeira and the Canary islands. Lanceostomatinae (Ostracoda) from the nearshore zone of Madeira and the Canary islands. Revista Española de Micropaleontología, 36(1), 57-81.

Shipman, P., 1981. Life history of a fossil. London, Harvard University Press, 288pp.

Short, A.D., 1999. Handbook of beach and shoreface morphodynamics. Chichester, Wiley, 379pp.

Storz, D., Schulz, H., Waniek, J.J., Schulz-Bull, D.E., Kucera, M., 2009. Seasonal and interannual variability of the planktic foraminiferal flux in the vicinity of the Azores Current. Deep-Sea Research I, 56, 107-124.

Spiegelhalter, D.J., Best, N.G., Carlin, B.P., van der Linde, A., 2002. Bayesian measures of model complexity and fit. Journal of the Royal Statistical Society, Series B, 64, 583-639.

Spiegelhalter, D.J., Thomas, A., Best, N.G., 2003. WinBUGS User Manual, Version 14. Cambridge, Medical Research Council Biostatistics Unit, 60pp. 
Tittley, I., Neto, A.I., 1995. The marine algal flora of the Azores and its biogeographical affinities. Boletim do Museu Municipal do Funchal, 4, 747-766.

Whatley, R.C., 1983. The application of Ostracoda to palaeoenvironmental analysis. In: Maddocks, R.F. (ed.). Applications of Ostracoda. Houston, University of Houston, Geoscience, 51-77.

Whatley, R.C., 1988. Population structure of ostracods: some general principles for recognition of paleoenvironments. In: De Deckker, P., Colin, J.-P., Peypouquet, J.P. (eds.). Ostracoda in the Earth Sciences. Elsevier, Amsterdam, 245-256.

Wilson, B., 2007. Recent Ostracoda of the Coconut and Mahogany fields, offshore SE Trinidad. Caribbean Journal of Science, 43(2), 181-188.

Wisshak, M., Form, A., Jakobsen, J., Freiwald, A., 2010. Temperate carbonate cycling and water mass properties from intertidal to bathyal depths (Azores, N-Atlantic). Biogeosciences, 7, 3297-3333.

Xavier, J.R., Van Soest, R.W.M., 2012. Diversity patterns and zoogeography of the Northeast Atlantic and Mediterranean shallow-water sponge fauna. Hydrobiologia, 687,107-125.

Zuur, A.F., Leno, E.N., Smith, G.M., 2007. Analysing ecological data. New York, Springer, 672pp. 


\section{TABLE CAPTIONS}

Table 1 Characterization of the sampling sites. Grain size abbreviations, Fs: fine sand; Ms: medium sand; Cs: coarse sand; G: gravel; n.a.: not applicable.

Table 2. Total number of live and dead specimens of ostracods by sites and by species. Sites $5,14,15,16,17,22,34,35,36$ and 38, contained living specimens; all other sites contained only dead specimens. For the complete list and geographical localization of the collecting sites, please consult Table 1. L. rho: Loxoconcha rhomboidea; L. mal: Loxoconcha malcomsoni; N. lon: Neonesidea longisetosa; A. con: Aurila convexa; A. wou: Aurila woutersi; X. rub: Xestoleberis rubens; X. cf. dep: Xestoleberis cf. depressa; H. alb: Heterocythereis albomaculata; U. bri: Urocythereis britannica; L. pel: Leptocythere pelúcida; C. whi: Carinocythereis whitei; Cal sp.: Callistocythere sp.; Sem sp.: Semicytherura sp.; Lan sp.: Lanceostoma sp.; Cyl sp.: Cylindroleberis sp.

Table 3 Total number and percentage of live and dead specimens of the different ostracod species collected in the Azores islands.

Table 4 Evaluation of four Bayesian models assessing the effect of five different factors (Location, Island, Depth, Habitat, Sediment) on the diversity (Eveness, Shannon Diversity, Total Abundance, Species Richness) of Holocene Ostracoda assemblages in the Azores Archipelago. DIC values obtained after convergence $(75,000$ model updates).

FIGURE CAPTIONS 
Figure 1 Geographical location of the Azores Archipelago (Western, Central and Eastern Groups), and the Azores Current (approximate position for the 30.6 meters depth and temperature; modified from Johnson and Stevens, 2000) around the archipelago. Insert: main oceanic currents of the North Atlantic Ocean; SF: Subpolar Front, NAC: North Atlantic Current, AC: Azores Current, AFZ: Azores Frontal Zone (adapted from Rogerson et al., 2004; Storz et al., 2009). The bathymetry of the Azores archipelago is from IOC IHO \& BODC (2003).

Figure 2 External view (SEM photographs) of the valves of the species of marine ostracods reported for the Azores archipelago. 1) Loxoconcha rhomboidea (Fischer, 1855). DB/OS 0144. L.V.; 2) Loxoconcha malcomsoni Horne and Robinson, 1985. DB/OS 0001. L.V.; 3) Xestoleberis rubens Whittaker, 1978. DB/OS 0118. L.V.; 4) Xestoleberis cf. depressa Sars, 1866. DB/OS 0181. L.V.; 5) Aurila convexa (Baird, 1850). DB/OS 0039. L.V.; 6) Aurila woutersi Horne, 1986. DB/OS 0120. L.V.; 7) Heterocythereis albomaculata (Baird, 1838). DB/OS 0113. L.V.; 8) Urocythereis britannica Athersuch, 1977. DB/OS 0017. L.V.; 9) Neonesidea longisetosa (Brady, 1902). DB/OS 0133. L.V.; 10) Carinocythereis whitei (Baird, 1850). DB/OS 0054. L.V.; 11) Callistocythere sp. DB/OS 0124. L.V.; 12) Semicytherura sp. DB/OS 0123. L.V.; 13) Lanceostoma sp. DB/OS 0117. L.V.; 14) Leptocythere pellucida (Baird, 1850). DB/OS 0057. R.V.; 15) Cylindroleberis sp. DB/OS 0180. R.V.

Figure 3 Geographical distribution of the Recent and Holocene marine ostracods from São Miguel Island. 1) Neonesidea longisetosa; 2) Aurila woutersi; 3 ) Heterocythereis albomaculata; 4) Carinocythereis whitei; 5) Loxoconcha rhomboidea; 6) Xestoleberis rubens; 7) Urocythereis britannica; 8) Aurila convexa; 9) Semicytherura sp.; 10) 
Callistocythere sp.; 11) Leptocythere pellucida; 12) Lanceostoma sp.; 13) Loxoconcha malcomsoni; 14) Cylindroleberis sp.

Figure 4 Total number of specimens for water depth classes. A) number of Recent (living) specimens, and B) number of autochthonous Holocene specimens.

Figure 5 Geographical distribution of the Recent marine ostracods from the Azores archipelago. 1) Loxoconcha rhomboidea; 2) Loxoconcha malcomsoni; 3) Xestoleberis rubens; 4) Xestoleberis cf. depressa 5) Urocythereis britannica; 6) Aurila convexa; 7) Neonesidea longisetosa; 8) Callistocythere sp.; 9) Heterocythereis albomaculata; 10) Aurila woutersi; 11) Lanceostoma sp.

Figure 6 Effect of the environmental factors (bathymetry and habitat) on the abundance and diversity of the ostracod communities in the Azores Archipelago (35 samples). Evaluation of Bayesian models assessing the effect of: A) Depth class on total abundance (depth classes, 1: $<10 \mathrm{~m} ; 2: 10-30 \mathrm{~m} ; 3:>30 \mathrm{~m}$ ); B) Habitat type on total abundance (beach; sublittoral; and tide pools); and C) Habitat type on species richness (beach; sublittoral, and tide pools). Bars represent mean+standard error. The posterior distributions of the parameters were obtained after convergence $(100,000$ model updates). Different letters indicate that the posterior distribution of the difference between the means does not include zero (based on the analysis of the $95 \%$ credibility interval).

Figure 7 Effect of the environmental factors (island) on the abundance and diversity of the ostracod communities in the Azores Archipelago (35 samples). Evaluation of a 
Bayesian model assessing the effect of island (Santa Maria, Formigas, São Miguel, Terceira, Pico, Faial, Graciosa and Flores) on the diversity of recent Ostracod communities in eight Azorean islands. Posterior distributions obtained after convergence $(100,000$ model updates). The model determined the effect of the factor island on total abundance, species richness, Eveness and Shannon Diversity index. Different letters indicate that the posterior distribution of the difference between the means does not include zero (based on the analysis of the $95 \%$ credibility interval).

Figure 8 Effect of the environmental factors (sediment sand size) on the abundance and diversity of the ostracod communities in the Azores Archipelago (35 samples). Evaluation of a Bayesian model assessing the effect of sand size on: A) total abundance; B) species richness. The posterior distributions of the parameters were obtained after convergence $(100,000$ model updates). Different letters indicate that the posterior distribution of the difference between the means does not include zero (based on the analysis of the $95 \%$ credibility interval).

Figure 9 Discriminant analysis applied on the distribution of the ostracod communities in eight Azorean islands (35 samples), according to the type of habitat (beach, sublittoral, tide pools). Discriminant analysis is based on individual species abundance, species richness and total abundance (all three log transformed), and also on the Shannon and Eveness diversity indices.

Figure 10 Distribution of ostracods as a function of depth, grain size and depositional environment. The sediment supply comes mainly from streams with an ephemeral 
torrential regime, or small permanent streams. Fine-sand: lower energy; medium sand: medium energy; coarse sand and gravel: higher energy ( $c f$. Electronic Appendix).

Figure 11 Cross-insular shelf profile with the maximum bathymetric range and distribution of the ostracods found in the Azores shallow marine environments, according to preferred bathymetry and type of sediment. 